\title{
Effects of Organic Selenium on Growth Properties, Selenium Absorption and Utilization, Antioxidant Activity and Immunity in Weaning Piglets
}

\author{
Weixian Zhang1*, Yong Li' ${ }^{2,3}$, Hongyu Deng1, Zheng Li', Ruiping Xiang', Jianlai Guo1, \\ Chunmei Pan ${ }^{*}$ \\ ${ }^{1}$ College of Animal Science and Technology, Henan University of Animal Husbandry and Economy, Zhengzhou, China \\ ${ }^{2}$ College of Agricultural and Animal Husbandry Engineering, Zhoukou Vocational and Technological College, Zhoukou, China \\ ${ }^{3}$ College of Animal Science and Technology, Gansu Agricultural University, Lanzhou, China \\ ${ }^{4}$ College of Veterinary Medicine, Henan University of Animal Husbandry and Economy, Zhengzhou, China \\ Email: *80812@hnuahe.edu.cn, *80525@hnuahe.edu.cn
}

How to cite this paper: Zhang, W.X., Li, Y., Deng, H.Y., Li, Z., Xiang, R.P., Guo, J.L. and Pan, C.M. (2020) Effects of Organic Selenium on Growth Properties, Selenium Absorption and Utilization, Antioxidant Activity and Immunity in Weaning Piglets. Food and Nutrition Sciences, 11, 385-395. https://doi.org/10.4236/fns.2020.115028

Received: April 20, 2020

Accepted: May 15, 2020

Published: May 18, 2020

Copyright $\odot 2020$ by author(s) and Scientific Research Publishing Inc. This work is licensed under the Creative Commons Attribution International License (CC BY 4.0).

http://creativecommons.org/licenses/by/4.0/

cc) (i) Open Access

\begin{abstract}
This experiment was conducted to determine the influences of adding organic selenium (Se) on growth properties, Se absorption and utilization, immunity and antioxidant activity in diets of Duroc weaning piglets. This study was performed on 36 (average weight $7.6 \mathrm{~kg}$ ) weaning piglets. The weaning piglets were randomly allocated to 1 of 4 homogeneous treatments (A, control treatment, no added Se; B, Sodium selenite, $0.3 \mathrm{mg} \mathrm{Se} / \mathrm{kg}$ feed; C, yeast Se, 0.3 $\mathrm{mg} \mathrm{Se} / \mathrm{kg} ; \mathrm{D}$, DL-methionine Se $0.3 \mathrm{mg} \mathrm{Se} / \mathrm{kg}$ ). Every treatment had 3 replicates, every replicate had 3 piglets. The experiment lasted for $35 \mathrm{~d}$, with the first $7 \mathrm{~d}$ for adaptation. Feed intake, residual and contaminated feed were recorded every day. Every piglet weight was weighted respectively at beginning and end of experiment. Daily intake, gain weight and feed conversion rates of every replicate were calculated finally. Se concentrations of serum, blood antioxidant and immunity index were analyzed in the 36th $\mathrm{d}$ of experiment. The results showed average daily gain of treatment $\mathrm{C}$ was significant higher $(P<0.05)$ and $\mathrm{D}$ had higher trend than that of treatment $\mathrm{A}$ and $\mathrm{B}(P=$ $0.06)$ respectively. And feed and gain ratio of $C$ and $D$ had trends to lower than them of A and B $(P=0.14)$. However, all the intake of every week and whole period had no significant differences among treatments $(P>0.05)$. At same time, except for the Immunoglobulin $M$ of treatment $D$ and $C$ was higher than that of treatment $\mathrm{A}$ and B significantly $(P<0.05)$, all the other Se contents of serum, immunity indexes, blood cell parameters and enzymatic activities had no significant differences among treatments $(P>0.05)$. But they
\end{abstract}


took on some obvious trends. For example, the Se contents and glutathione peroxidase activities increased successively in order of treatment $A, B, C$ and $\mathrm{D}$; the blood urea nitrogen and total bilirubin of treatment $\mathrm{A}$ had higher trend than that of other treatments $(P=0.06)$. All in all, adding to organic Se in basal diets could improve the animal's healthy levels, growth properties and Se utilization to some extent. Relatively speaking, the DL-methionine Se had more advantages compared to yeast Se.

\section{Keywords}

Se Absorption and Utilization, Growth Properties, Antioxidant Activity and Immunity, Weaning Piglets

\section{Introduction}

Selenium (Se) is an essential trace element for human and animal health, which has effects on anticancer, antioxidant, anti-cardiovascular diseases, strengthening antioxidant and immunity capacity, promoting growth and improving meat qualities, and so on [1] [2]. If the piglets are short of Se, they will appear muscular dystrophy, exudative diathesis, necrotic liver degeneration, and mulberry heart disease in farm animals [3]. To meet the Se need of piglets, the people often add a certain amount of inorganic Se in diets, for example, sodium selenite (SS). However, SS has lots of disadvantages such as potential toxic at high dietary level, low absorption rates, and potential pro-oxidation defects [4]. Thus, organic Se, for example DL-methionine Se and yeast Se, has received more attention in the additive industry during recent years [5]. However, the main Se compound present in yeast Se is L-selenomethionine based on previous research [6] [7]. Additionally, L-selenomethionine represents the exclusive form in natural selenomethionine compounds and the other stereoisomer is the D-selenomethionine form [8]. DL-selenomethionine is a synthetic product that has an equimolar mixture of D-selenomethionine and L-selenomethionine [9]. So, the DL-selenomethionine may be more effective for the Se additive than organic Se-enriched yeast. Some research results showed that selenomethionine could improve anti-oxidative capacity and meat quality of broilers or finishing pigs [10] [11]. But there's few study conducted to compare DL-methionine Se with yeast Se and SS, or to compare their effects on improving the antioxidant activity and Se status in weaning pig diets in China and elsewhere [12]. Hence, the objective of experiment is to compare the effects of DL-methionine Se, yeast Se and SS on growth properties, antioxidant and immunity capacities and Se contents of serum in weaning piglets.

\section{Materials and Methods}

\subsection{Animal, Diets, and Experimental Design}

The 36 (average weight $7.6 \mathrm{~kg}$ ) weaning piglets (weaned on $\mathrm{d} 28$ ) were randomly 
allocated to 1 of 4 homogeneous treatments (A, control treatment, no added Se; B, SS, $0.3 \mathrm{mg} \mathrm{Se} / \mathrm{kg}$ feed; yeast Se, $0.3 \mathrm{mg} \mathrm{Se} / \mathrm{kg}$; DL-methionine Se $0.3 \mathrm{mg}$ $\mathrm{Se} / \mathrm{kg}$ ). SS, yeast Se and DL-methionine Se were added to the basal diets at the expense of premix. Every treatment had 3 replicates, every replicate had 3 piglets

The experiment lasted for $35 \mathrm{~d}$, with the first $7 \mathrm{~d}$ for adaptation. The SS was bought from Guangxi Nanning Jun Wei: Feed Co., LTD, and its content is 1000 $\mathrm{mg} / \mathrm{kg}$ in product. The yeast Se and DL-methionine Se were bought respectively from Le Fu yeast companies in the Unites States and Puno (Chengdu) biological technology co., LTD, and their contents are $2000 \mathrm{mg} / \mathrm{kg}$ in product. The piglets of every group was closed in a house with access to water and feed ad libitum. During the course of experiment, all the experiment houses were well ventilated and dried, and kept temperature $25^{\circ} \mathrm{C}-28^{\circ} \mathrm{C}$ and relative humidity $55 \%-70 \%$. Furthermore, the experiment houses were swept and fumigated twice at am 8:00 and pm 14:00 every day.

The formula and nutrient levels of the experiment diet are presented in Table 1.

Table 1. Ingredients and nutrient content of the basal diet (DM basis).

\begin{tabular}{|c|c|}
\hline Ingredients & $\%$ \\
\hline Corn & 66.3 \\
\hline Peeled soybean meal & 21.6 \\
\hline Whey power & 4.9 \\
\hline Imported fish meal & 2.9 \\
\hline $\mathrm{CaHPO}_{4}$ & 0.8 \\
\hline Limestone & 0.8 \\
\hline Soybean oil & 0.7 \\
\hline Lysine & 0.4 \\
\hline Acidifiers & 0.3 \\
\hline $\mathrm{NaCl}$ & 0.2 \\
\hline DL-Methionine & 0.1 \\
\hline Threonine & 0.1 \\
\hline Premix & 0.9 \\
\hline In total ${ }^{1}$ & 100 \\
\hline Nutrient levels & $\%$ \\
\hline Digestive energy (MJ/kg, DM) & 14.0 \\
\hline Crude protein ${ }^{2}$ & 18.5 \\
\hline Calcium $^{2}$ & 0.75 \\
\hline Phosphorus $^{2}$ & 0.60 \\
\hline Lysine & 1.30 \\
\hline L-Methionine & 0.45 \\
\hline Threonine & 0.80 \\
\hline
\end{tabular}

Note: ${ }^{1}$ Provided per kilogram of diet: vitamin A 11,000 IU, vitamin $\mathrm{D}_{3} 1500 \mathrm{IU}$, vitamin E 44.1 IU, vitamin $\mathrm{K}_{3} 4.0 \mathrm{mg}$, vitamin $\mathrm{B}_{1} 1.4 \mathrm{mg}$, vitamin $\mathrm{B}_{2} 5.22 \mathrm{mg}$, vitamin $\mathrm{B}_{5} 20.0 \mathrm{mg}$, vitamin $\mathrm{B}_{12} 0.01 \mathrm{mg}$, niacin $26.0 \mathrm{mg}$, pantothenic acid $14 \mathrm{mg}$, folic acid $0.8 \mathrm{mg}$, biotin $44 \mu \mathrm{g}$, Fe $100.0 \mathrm{mg}$, Cu $16.50 \mathrm{mg}$, Zn $90.0 \mathrm{mg}$, Mn $35.0 \mathrm{mg}$, I $0.30 \mathrm{mg} .{ }^{2}$ Crude proteins, Calcium, Phosphorus were measured. The Se content of basal diet was 0.04 $\mathrm{mg} / \mathrm{kg} \mathrm{DM}$. Other values were calculated based on data from the diet supplier. 
The basal diets and premix were all prepared according to the People's Republic of China feed standard in piglets (2004) by Henan Hyrum Feed Co., LED. And the feeds were offered 4 times per day, respectively 8:00am, 12:00am, 16:00pm, 20:00pm. All ingredients were same except for Se sources in four diets.

\subsection{Sampling, Measurement, and Analyses}

Intake, residual and contaminated feed were recorded every day. Every piglet weight gain was weighted respectively at beginning and end of experiment. Daily intake, weight gain and feed and gain ratios of every replicate were calculated finally.

Before intake and water in the morning, the $5 \mathrm{ml}$ blood samples $(2 \mathrm{ml}$ anti-clotting and $3 \mathrm{ml} \mathrm{no}$ anti-clotting) were collected from the front cavity vein of piglets among 4 treatments (one piglet/treatment replicate) in the 36th $\mathrm{d}$ of experiment. The collected $2 \mathrm{ml}$ anti-clotting blood then centrifuged at $4000 \mathrm{rpm}$ for $10 \mathrm{~min}$ at $4^{\circ} \mathrm{C}$ to collect serum, which was frozen at $-20^{\circ} \mathrm{C}$ until analyzed. Serum samples were later thawed and analyzed for quantification of glutathione peroxidase (GSH-px), aspartate aminotransferase (AST), alanine aminotransferase (ALT), gamma-glutamyltransferase (GGT), alkaline phosphatise (ALP), total protein (TP), albumin (ALB), blood urea nitrogen (BUN), creatinine (CREA), glucose (GLU), total bilirubin (TBIL), cholesterol (CHOL), immunoglobulin A (IgA), immunoglobulin G (IgG), immunoglobulin M (IgM) were determined according to method described in other studies [13] [14] [15].

Another $3 \mathrm{ml}$ no anti-clotting blood was placed into a 10-mL tube for whole blood variable determination immediately. The whole blood samples were used to determine red blood cell count (RBC), haematocrit concentration (HCT), haemoglobin concentration (HGB), and white blood cell count (WBC), platelet (PLT) according to method reported previously [16].

Additionally, the Se concentration of serum was determined by a SpectorAA-30 atomic absorption spectrophotometer (Varian Techtron. Pty. Ltd., Mulgrave, Victoria, Australia).

\subsection{Calculations and Statistical Analysis}

Statistical analysis was conducted using SAS 9.1.3. All data were analyzed using the MIXED procedure. Piglets within treatment were subjected as random to test for main effects and interactions using the covariance type AR (1), and the residual error was used to test for week and week $\times$ treatment interaction. Mean comparisons across treatments were made when the interaction terms of the model were significant $(P<0.05)$ using LSMEANS and PDIFF separation of all the treatments. Significant differences were declared at $P<0.05$ and trends at $0.05 \leq P \leq 0.10$.

\section{Results}

\subsection{Growth Properties}

The effects of organic Se on growth properties were shown in Table 2. We could 
Table 2. Effects of organic selenium on intake and daily gain of piglets.

\begin{tabular}{lccccccc}
\hline Controls & $\begin{array}{c}\text { The first week } \\
\text { intake }(\mathrm{g})\end{array}$ & $\begin{array}{c}\text { The second week } \\
\text { intake }(\mathrm{g})\end{array}$ & $\begin{array}{c}\text { The third week } \\
\text { intake }(\mathrm{g})\end{array}$ & $\begin{array}{c}\text { The fourth week } \\
\text { intake }(\mathrm{g})\end{array}$ & $\begin{array}{c}\text { The whole period } \\
\text { intake }(\mathrm{g})\end{array}$ & $\begin{array}{c}\text { Average daily } \\
\text { gain }(\mathrm{g})\end{array}$ & $\begin{array}{c}\text { Feed and gain } \\
\text { ratio }(\mathrm{F} / \mathrm{G})\end{array}$ \\
\hline $\mathrm{A}(\mathrm{n}=3)$ & $464 \pm 59$ & $631 \pm 46$ & $772 \pm 30$ & $876 \pm 41$ & $686 \pm 163$ & $321^{\mathrm{b}} \pm 40$ & $2.14 \pm 0.12$ \\
$\mathrm{~B}(\mathrm{n}=3)$ & $456 \pm 34$ & $636 \pm 55$ & $769 \pm 28$ & $870 \pm 49$ & $683 \pm 162$ & $314^{\mathrm{b}} \pm 63$ & $2.20 \pm 0.28$ \\
$\mathrm{C}(\mathrm{n}=3)$ & $476 \pm 32$ & $645 \pm 49$ & $770 \pm 27$ & $870 \pm 46$ & $690 \pm 154$ & $419^{\mathrm{a}} \pm 128$ & $1.72 \pm 0.34$ \\
$\mathrm{D}(\mathrm{n}=3)$ & $492 \pm 34$ & $652 \pm 38$ & $761 \pm 27$ & $877 \pm 51$ & $695 \pm 149$ & $385^{\mathrm{ab}} \pm 116$ & $1.82 \pm 0.27$ \\
\hline
\end{tabular}

Note: In the same column, values with different capital and small letters mean very significant difference at $P<0.01$ and significant difference at $P<0.05$.

know that average daily gain of treatment $\mathrm{C}$ was significant higher $(P<0.05)$ and $\mathrm{D}$ had higher trend than that of treatment $\mathrm{A}$ and $\mathrm{B}(P=0.06)$ respectively. And feed and gain ratio of $\mathrm{C}$ and $\mathrm{D}$ had trends to lower than them of $\mathrm{A}$ and $\mathrm{B}(P$ $=0.14)$. However, all the intake of every week and whole period had no significant differences among treatments $(P>0.05)$.

\subsection{Se Contents in Serum, Immunity Indexes, Blood Cell and Biochemistry Parameters}

The effects of organic Se on Se contents in serum, immunity indexes, blood cell and biochemistry parameters were shown in Tables 3-6. Except for the IgM of treatment $\mathrm{D}$ and $\mathrm{C}$ was higher than them of treatment $\mathrm{A}$ and $\mathrm{B}$ significant $(P<$ 0.05 ), all the other Se contents of serum, immunity indexes, blood cell parameters and enzymatic activities had no significant differences among treatments $(P>0.05)$. But they took on some obvious trends. For example, the Se contents and GSH-Px activities increased successively in order of treatment A, B, C and $\mathrm{D}$; the BUN and TBIL of treatment $\mathrm{A}$ had higher trend than them of other treatments $(P=0.06)$.

\section{Discussion}

The effects of Se on growth performance of animals are somewhat variable. It was reported that different Se sources and levels did not effect on the average daily gain weight, intake and feed and meat ratio among the groups [17] [18] [19]. However, Jiang et al. (2009) suggested that $0.225 \mathrm{mg} / \mathrm{kg}$ of selenomethionine could highly improve the growth performance of broilers [10]. Zhan et al. (2011) reported that maternal selenomethionine intake of $0.3 \mathrm{mg} / \mathrm{kg}$ significantly increased the average weight gain of piglets from birth to weaning compared with the $0.3 \mathrm{mg} / \mathrm{kg}$ SS group [20]. In this experiment, all the intake of every week and whole period had no significant differences among groups $(P>0.05)$, but average daily gain of treatment $\mathrm{C}$ was significant higher $(P<0.05)$ and $\mathrm{D}$ had higher trend than that of treatment $\mathrm{A}$ and $\mathrm{B}(P=0.06)$ respectively, which led to lower feed and gain rates of treatment $\mathrm{C}$ and $\mathrm{D}$ compared to them of treatment A and B $(P=0.14)$. It was consistent with their reports. Wang et al. (1997) suggested Se from organic sources was more available than inorganic Se for growth [21]. The present study indicated that organic Se had a positive effect on the 
Table 3. Effects of organic selenium on Se contents in serum and immunity of piglets.

\begin{tabular}{ccccc}
\hline Controls & Se in serum $(\mathrm{mg} / \mathrm{kg})$ & $\operatorname{IgA}(\mathrm{g} / \mathrm{L})$ & $\operatorname{IgG}(\mathrm{g} / \mathrm{L})$ & $\operatorname{IgM}(\mathrm{g} / \mathrm{L})$ \\
\hline $\mathrm{A}(\mathrm{n}=3)$ & $0.12 \pm 0.02$ & $0.06 \pm 0.02$ & $3.69 \pm 0.81$ & $0.74^{\mathrm{b}} \pm 0.26$ \\
$\mathrm{~B}(\mathrm{n}=3)$ & $0.13 \pm 0.03$ & $0.03 \pm 0.01$ & $4.11 \pm 0.45$ & $0.62^{\mathrm{b}} \pm 0.25$ \\
$\mathrm{C}(\mathrm{n}=3)$ & $0.13 \pm 0.01$ & $0.04 \pm 0.02$ & $4.58 \pm 1.05$ & $1.04^{\mathrm{a}} \pm 0.31$ \\
$\mathrm{D}(\mathrm{n}=3)$ & $0.17 \pm 0.06$ & $0.10 \pm 0.14$ & $4.44 \pm 0.91$ & $1.30^{\mathrm{a}} \pm 0.20$ \\
\hline
\end{tabular}

1) In the same column, values with different capital and small letters mean very significant difference at $P<$ 0.01 and significant difference at $P<0.05$. 2) IgA, Immunoglobulin A; IgG, Immunoglobulin G; IgM, Immunoglobulin $\mathrm{M}$.

Table 4. Effects of organic selenium on blood cell parameters of piglets.

\begin{tabular}{cccccc}
\hline Controls & $\begin{array}{c}\mathrm{RBC} \\
\left(\text { quantities } \times 10^{12} / \mathrm{L}\right)\end{array}$ & $\begin{array}{c}\mathrm{WBC} \\
\left(\text { quantities } \times 10^{10} / \mathrm{L}\right)\end{array}$ & $\begin{array}{c}\mathrm{PLT} \\
\left.\text { (quantities } \times 10^{11} / \mathrm{L}\right)\end{array}$ & $\begin{array}{c}\mathrm{HGB} \\
(\mathrm{g} / \mathrm{L})\end{array}$ & $\begin{array}{c}\text { HCT } \\
(\%)\end{array}$ \\
\hline $\mathrm{A}(\mathrm{n}=3)$ & $6.91 \pm 0.79$ & $2.84 \pm 0.59$ & $1.38 \pm 0.53$ & $111 \pm 11$ & $41.4 \pm 3.7$ \\
$\mathrm{~B}(\mathrm{n}=3)$ & $6.72 \pm 0.76$ & $3.57 \pm 0.64$ & $3.00 \pm 0.97$ & $102 \pm 14$ & $38.2 \pm 5.3$ \\
$\mathrm{C}(\mathrm{n}=3)$ & $6.54 \pm 0.59$ & $2.27 \pm 0.35$ & $3.34 \pm 1.76$ & $107 \pm 13$ & $39.6 \pm 4.5$ \\
$\mathrm{D}(\mathrm{n}=3)$ & $6.27 \pm 0.88$ & $3.16 \pm 0.82$ & $2.59 \pm 0.51$ & $100 \pm 12$ & $37.6 \pm 3.8$ \\
\hline
\end{tabular}

RBC, red blood cell count; WBC, white blood cell count; PLT, platelet; HGB, haemoglobin concentration; HCT, haematocrit concentration.

Table 5. Effects of organic selenium on blood biochemistry parameters of piglets.

\begin{tabular}{lccccccc}
\hline Controls & TP $(\mathrm{g} / \mathrm{L})$ & ALB $(\mathrm{g} / \mathrm{L})$ & $\begin{array}{c}\text { BUN } \\
(\mathrm{m} \mathrm{mol} / \mathrm{L})\end{array}$ & $\begin{array}{c}\text { CREA } \\
(\mathrm{u} \mathrm{mol} /)\end{array}$ & $\begin{array}{c}\text { GLU } \\
(\mathrm{m} \mathrm{mol} / \mathrm{L})\end{array}$ & $\begin{array}{c}\mathrm{CHOL} \\
(\mathrm{m} \mathrm{mol} / \mathrm{L})\end{array}$ & $\begin{array}{c}\text { TBIL } \\
(\mathrm{u} \mathrm{mol} / \mathrm{L})\end{array}$ \\
\hline $\mathrm{A}(\mathrm{n}=3)$ & $53.9 \pm 7.0$ & $25.6 \pm 2.9$ & $5.52 \pm 1.48$ & $119 \pm 22$ & $2.42 \pm 1.61$ & $3.63 \pm 0.97$ & $3.20 \pm 3.07$ \\
$\mathrm{~B}(\mathrm{n}=3)$ & $56.3 \pm 4.4$ & $24.0 \pm 2.4$ & $3.65 \pm 0.60$ & $96 \pm 13$ & $1.84 \pm 1.25$ & $2.41 \pm 0.32$ & $0.43 \pm 0.17$ \\
$\mathrm{C}(\mathrm{n}=3)$ & $50.5 \pm 3.8$ & $25.5 \pm 5.9$ & $4.24 \pm 0.18$ & $203 \pm 198$ & $2.27 \pm 0.84$ & $2.74 \pm 0.40$ & $0.35 \pm 0.13$ \\
$\mathrm{D}(\mathrm{n}=3)$ & $55.5 \pm 8.4$ & $22.9 \pm 6.0$ & $4.94 \pm 0.39$ & $99 \pm 16$ & $1.75 \pm 0.72$ & $3.70 \pm 1.83$ & $0.40 \pm 0.19$ \\
\hline
\end{tabular}

TP, total protein; ALB, albumin; BUN, blood urea nitrogen, CREA, creatinine; GLU, glucose; CHOL, cholesterol; TBIL, total bilirubin.

Table 6. Effects of organic selenium on blood enzymatic activities of piglets.

\begin{tabular}{cccccc}
\hline Controls & $\begin{array}{c}\text { GSH-PX } \\
\text { Activities (U/ml) }\end{array}$ & ALT (U/L) & AST (U/L) & GGT (U/L) & ALP (U/L) \\
\hline A (n=3) & $550 \pm 105$ & $59.8 \pm 18.0$ & $101 \pm 21$ & $150 \pm 61$ & $153 \pm 62$ \\
B (n=3) & $588 \pm 85$ & $81.0 \pm 15.3$ & $117 \pm 22$ & $275 \pm 38$ & $239 \pm 105$ \\
C (n=3) & $622 \pm 76$ & $69.3 \pm 20.4$ & $77 \pm 25$ & $246 \pm 17$ & $311 \pm 120$ \\
D (n=3) & $683 \pm 91$ & $64.0 \pm 15.3$ & $114 \pm 26$ & $354 \pm 48$ & $176 \pm 22$ \\
\hline
\end{tabular}

GSH-PX, glutathione peroxidase; ALT, alanine aminotransferase; AST, aspartate amino transferase; GGT, gamma-glutamyltransferase; ALP, alkaline phosphatise.

growth performance. The underlying mechanism might be they elevated health levels of animals and thus improved the growth performance of weaning piglets [4]. We suggested that DL-selenomethionine and yeast Se exhibited higher ab- 
sorption and utilization efficiency than SS and could provide as an effective additive for weaning piglets to improve its growth performance.

Mahan and Peters (2004) reported that organic Se showed a higher potential to improve the Se status in the piglets [17]. Zhan et al. (2011) also reported that selenomethionine exhibited to be more effective to increase the Se content in all tissues of serum, liver, kidney, pancreas, muscle, and thymus and thyroid gland in weaned pigs at 28 days [20]. Kim and Mahan (2001) found that, compared with SS, the plasma Se concentration approximately doubled when Se-enriched yeast was fed. Addtional, IgG, $\lg A, \operatorname{lgM}$ are the immunoglobulin of human and animals [22]. Among them, the IgG is the most important one. Its main function is playing a role of protection in the immunization of bodies. Adequate intake of Se is required to ensure optimal immune function [18]. Peplowski et al. (1980) indicated that Se provided in diet or by injection increased the immune response of weaning pigs [23]. In this experiment, the Se contents of serum, IgA, IgG had no significant differences among treatments $(P>0.05)$, but the Se contents increased successively in order of treatment A, B, C and D, and the IgM of treatment $\mathrm{D}$ and $\mathrm{C}$ was higher than that of treatment $\mathrm{A}$ and $\mathrm{B}$ significantly $(P<0.05)$. They were consistent with the other's results. So it was showed that organic Se had higher absorption and utilization rates, and was benefit to improve immunity and resistance of weaning piglets. Especially, the DL-methionine Se had more advantages compared to yeast Se. The possible mechanism of absorption and utilization between inorganic and organic Se might be explained by the differences of metabolic pathways. Se in both forms can be incorporated into GSH-Px, but selenomethionine might also be incorporated in other proteins in substitution for methionine [24] [25]. Selenomethionine could be effectively metabolized to a Se analogue of S-adenosylmethionine, and was further metabolized in transmethylation reactions and in polyamine synthesis, similarly to the corresponding sulphur metabolites of methionine [26]. On the other hand, DL-methionine Se had more advantages compared to yeast Se in the way of Se absorption and utilization rates. The possible reasons were DL-methionine Se included D-methionine and L-methionine, and yeast Se only had L-methionine.

The research showed the RBC increasing in quantities might promote the WBC phagocytic functions, improve the body's ability to deliver oxygen in blood, strengthen immunity and metabolic functions. However, the WBC, neutrophils and lymphocyte are the important indexes indicated immunity of animal bodies, and the changes of quantities are the stronger or weaker expression of cell [27]. In this experiment, the blood cell parameters had no significant differences among groups $(P>0.05)$, and did not appear obvious change. It was showed the selenium sources did not effect on immunity of weaning piglets obviously. It was consistent with the experimental results of laying hens. However, in our 84-d dairy experiment, it was found that the RBC and WBC of $0.3 \mathrm{mg} / \mathrm{kg}$ Se DL-methionine treatment are very higher than them of control and $0.3 \mathrm{mg} / \mathrm{kg}$ SS treatment significantly in the whole blood $(P<0.01)$ [28]. This maybe showed the change of blood cell parameters and improvement of immunologic functions 
were relate to the Se sources and longer or shorter time of feeding. The specific reasons need to further discusses and study in depth.

The changes of blood biochemistry parameters are the reflex of permeability changes of tissue and cell and metabolism function changes of bodies. ALT exists in cytoplasm of dogs, cats and primates mainly and so on, and it is one of the most sensitive liver function test index of the animals. The AST contents are higher in liver cells, hearts and skeletal muscles and they can be used to explore the extensive organizational damages. Normally the AST increasing of cattle and goats often occurs in hepatic necrosis symptoms caused by all kinds of reasons [29]. ALP takes part in many biochemical metabolic pathways in animal's bodies, and comes from skeletal muscles and intestinal mucosa mainly. In normal, the ALP passes bile ducts and drains into with bile by liver cell activities. But when intestinal tract is blocked or liver suffer from disease, the ALP activities are improved greatly in serum [30]. GGT exists in the liver cell membrane and mitochondria mainly, and takes part in glutathione peptide metabolism. But the GGT comes from hepatobiliary system mainly in serum. When intrahepatic function hyper or stopping the bile exhaustion, the GGT contents increase in serum [31].

Se is active ingredient of GSH-PX. However the GSH-PX activity determination in plasma of piglets is the important indexes of measuring Se levels and antioxidant capacity of animal bodies. It is widely accepted that proper Se intake improved the antioxidant status of the body in any form of Se. In general, organic Se-enriched yeast showed more potential to improve the antioxidant status than inorganic Se [32] [33]. Zhan et al. (2007) reported that selenomethionine was superior to improve antioxidant status in finishing pigs when compared with SS [5].

In this experiment, the enzymatic activities had no significant differences among treatments $(P>0.05)$, but the GSH-Px activities increased successively in order of treatment A, B, C and D. It showed adding organic Se could improve the GSH-Px activities and body's antioxidant capacity. On the other hand, the GSH-Px activities of DL-selenomethionine were the highest among all treatments which showed DL-selenomethionine had more advantages compared to yeast Se. This was consistent with the other results.

\section{Conclusion}

In this experiment, adding to organic Se had improved the animal's healthy level, growth properties, Se utilization and antioxidant capacity to some extent. Relatively speaking, DL-methionine Se had more advantages in all kinds of ways. We suggested that organic Se, especially DL-selenomethionine, exhibited higher absorption and utilization efficiency, better antioxidant capacity than SS and could provide as an effective additive for weaning piglets to improve its growth performance. Hence, DL-selenomethionine, a pure organic Se source, would have bright implication in feed additives of the weaning piglets industry. 


\section{Acknowledgements}

This work was supported by Henan Provincial Department of International Technical Cooperation Foundation (Project \#162102410028) and the key Projects of Scientific and Technological Research in the Department of Education of Henan Province (Zhengzhou, China; No. 14B230019), and the Chair Programs Fund from the Henan Key Lab of Unconventional Feed Resources Innovation and Utilization. Here we are also grateful to the technical staffs of experimental center and testing center in the Henan Key Lab of Unconventional Feed Resources Innovation and Utilization for their help in this work. Also, staff members of Chuying agricultural and animal husbandry limited company, Weishi branch office (Kaifeng, China) are appreciated for their care for the experimental weaning piglets used in this study.

\section{Conflicts of Interest}

The authors declare no conflicts of interest regarding the publication of this paper.

\section{References}

[1] Burk, R.F., Hill, K.E. and Motley, A.K. (2003) Selenoprotein Metabolism and Function: Evidence for More than One Function for Selenoprotein. Journal of Nutrition, 133, 1517-1520. https://doi.org/10.1093/jn/133.5.1517S

[2] Surai, P. (2006) Selenium in Nutrition and Health. Nottingham University Press, Nottingham.

[3] Zarczynska, K., Sobiech, P., Radwinska, J. and Rekawek, W. (2012) Effects of Selenium on Animal Health. Journal of Elementology, 18, 329-340. https://doi.org/10.5601/jelem.2013.18.2.12

[4] Hu, H.J., Wang, M., Zhan, X.A., Li, X. and Zhao, R.Q. (2011) Effect of Different Selenium Sources on Productive Performance, Serum and Milk Se Concentrations, and Antioxidant Status of Sows. Biological Trace Element Research, 142, 471-480. https://doi.org/10.1007/s12011-010-8803-1

[5] Zhan, X.A., Wang, M., Zhao, R.Q., Li, W.F. and Xu, Z.R. (2007) Effects of Different Selenium Source on Selenium Distribution, Loin Quality and Antioxidant Status in Finishing Pigs. Animal Feed Science and Technology, 132, 202-211. https://doi.org/10.1016/j.anifeedsci.2006.03.020

[6] Mendez, S.P., Gonzalez, E.B. and Medel, A.S. (2000) Chiral Speciation and Determination of Selenomethionine Enantiomers in Selenized Yeast by HPLC-ICP-MS Using a Teicoplanin-Based Chiral Stationary Phase. Journal of Analytical Atomic Spectrometry, 15, 1109-1114. https://doi.org/10.1039/B001579M

[7] Huang, X., Wang, J., Wang, Q. and Huang, B. (2005) Chiral Speciation and Determination of DL-Selenomethionine Enantiomers on a Novel Chiral Ligand-Exchange Stationary Phase. Analytical Sciences, 21, 253-257. https://doi.org/10.2116/analsci.21.253

[8] Cukierski, M.J., Willhite, C.C., Lasley, B.L., Hendrie, T.A., Book, S.A., Cox, D.N. and Hendrickx, A.G. (1989) 30-Day Oral Toxicity Study of L-Selenomethionine in Female Long-Tailed Macaques. Fundamental Toxicological Sciences, 13, 26-39. https://doi.org/10.1093/toxsci/13.1.26 
[9] Jing, C.L., Dong, X.F., Wang, Z.M., Liu, S. and Tong, J.M. (2015) Comparative Study of DL-Selenomethionine vs Sodium Selenite and Seleno-Yeast on Antioxidant Activity and Selenium Status in Laying Hens. Poultry Science, 94, 965-975. https://doi.org/10.3382/ps/pev045

[10] Jiang, Z.Y., Lin, Y.C., Zhou, G.L., Luo, L.H., Jiang, S.Q. and Chen, F. (2009) Effects of Dietary Selenomethionine Supplementation on Growth Performance, Meat Quality and Antioxidant Property in Yellow Broilers. Journal of Agricultural and Food Chemistry, 57, 9769-9772. https://doi.org/10.1021/jf902411c

[11] Jiang, Z.Y., Wang, Y., Lin Y.C., Zheng, C.T., Jiang, S.Q. and Chen, F. (2010) Effects of Dietary Selenomethionine Supplementation on Performance and Meat Quality of Finishing Pigs. Chinese Journal of Animal Nutrition, 22, 293-300.

[12] Cao, J., Guo, F.C., Zhang, L.Y., Dong, B. and Gong, L.M. (2014) Effects of Dietary Selenomethionine Supplementation on Growth Performance, Antioxidant Status, Plasma Selenium Concentration, and Immune Function in Weaning Pigs. Journal of Animal Science and Biotechnology, 5, 46. https://doi.org/10.1186/2049-1891-5-46

[13] Dubreuil, P., Petitclerc, D., Pelletier, G., Gaudreau, P., Farmer, C., Mowles, T.F. and Brazeau, P. (1990) Effect of Dose and Frequency of Administration of a Potent Analog of Human Growth Hormone-Releasing Factor on Hormone Secretion and Growth in Pigs. Journal of Animal Science, 68, 1254-1268. https://doi.org/10.2527/1990.6851254x

[14] Davidson, S., Hopkins, B.A., Odle, J., Brownie, C., Fellner, V. and Whitlow, L.W. (2008) Supplementing Limited Methionine Diets with Rumen-Protected Methionine, Betaine, and Choline in Early Lactation Holstein Cows. Journal of Dairy Science, 91, 1552-1559. https://doi.org/10.3168/jds.2007-0721

[15] Shantouf, R., Kovesdy, C.P., Kim, Y., Ahmadi, N., Luna, A., Luna, C., Rambod, M., Nissenson, A.R., Budoff, M.J. and Kalantar-Zadeh, K. (2009) Association of Serum Alkaline Phosphatase with Coronary Artery Calcification in Maintenance Hemodialysis Patients. Clinical Journal of the American Society of Nephrology, 4, 1106-1114. https://doi.org/10.2215/CJN.06091108

[16] Faggio, C., Fazio, F., Marafioti, S., Arfuso, F. and Piccione, G. (2015) Oral Administration of Gum Arabic: Effects on Haematological Parameters and Oxidative Stress Markers in Mugil Cephalus. Iranian Journal of Fisheries Sciences, 14, 60-72.

[17] Mahan, D.C. and Peters, J.C. (2004) Long-Term Effects of Dietary Organic and Inorganic Selenium Sources and Levels on Reproducing Sows and Their Progeny. Journal of Animal Science, 82, 1343-1358. https://doi.org/10.2527/2004.8251343x

[18] Gelderman, A. and Clapper, J. (2013) Effects of Inorganic or Organic Selenium on Immunoglobulins in Swine. Journal of Animal Science and Biotechnology, 4, 47. https://doi.org/10.1186/2049-1891-4-47

[19] Payne, R.L. and Southern, L.L. (2005) Comparison of Inorganic and Organic Selenium Sources for Broilers. Poultry Science, 84, 898-902.

https://doi.org/10.1093/ps/84.6.898

[20] Zhan, X.A., Qie, Y.Z., Wang, M., Li, X. and Zhao, R.Q. (2011) Selenomethionine: An Effective Selenium Source for Sow to Improve Se Distribution, Antioxidant Status, and Growth Performance of Pig Offspring. Biological Trace Element Research, 142, 481-491. https://doi.org/10.1007/s12011-010-8817-8

[21] Wang, C. and Lovell, R.T. (1997) Organic Selenium Sources, Selenomethionine and Selenoyeast, Have Higher Bioavailability than an Inorganic Selenium Source, Sodium Selenite, in Diets for Channel Catfish (Ictalurus punctatus). Aquaculture, 152, 223-234. https://doi.org/10.1016/S0044-8486(96)01523-2 
[22] Kim, Y.Y. and Mahan, D.C. (2001) Effect of Dietary Selenium Source, Level, and Pig Hair Color on Various Selenium Indices. Journal of Animal Science, 79, 949-955. https://doi.org/10.2527/2001.794949x

[23] Peplowski, M.A., Mahan, D.C., Murray, F.A., Moxon, A.L., Cantor, A.H. and Ekstrom, K.E. (1980) Effect of Dietary and Injectable Vitamin E and Selenium in Weanling Swine Antigenically Challenged with Sheep Red Blood Cells. Journal of Animal Science, 51, 344-351. https://doi.org/10.2527/jas1980.512344x

[24] Kim, Y.Y. and Mahan, D.C. (2003) Biological Aspects of Selenium in Farm Animals. Asian-Australasian Journal of Animal Sciences, 16, 435-444. https://doi.org/10.5713/ajas.2003.435

[25] Schrauzer, G.N. (2000) Selenomethionine: A Review of Its Nutritional Significance, Metabolism and Toxicity. Journal of Nutrition, 130, 1653-1656. https://doi.org/10.1093/jn/130.7.1653

[26] Beilstein, M.A. and Whanger, P.D. (1986) Deposition of Dietary Organic and Inorganic Se in Rat Erythrocyte Proteins. Journal of Nutrition, 116, 1701-1710. https://doi.org/10.1093/jn/116.9.1701

[27] Zhao, Y.J., Guo, J.Q., Zhang, Y., Wang, X., Wang, R. and Li, J. (2012) Effects of Tomato Pomace Fermented Feed on Production Performance, Milk Ingredients and Blood Cell Parameters in Xinjiang Brown Cattle. Xinjiang Journal of Agricultural Science, 49, 1546-1551.

[28] Li, Y., Liu, J.X., Xiong, J.L., Wang, Y.M., Zhang, W.X. and Wang, D.M. (2019) Effect of Hydroxy Selenomethionine on Lactation Performance, Blood Profiles, and Transfer Efficiency in Early-Lactating Dairy Cows. Journal of Dairy Science, 102, 6167-6173. https://doi.org/10.3168/jds.2019-16241

[29] Lei, Q.X. and Li, F.C. and Wu, H.T. (2003) Effects of Different Protein Levels on Production Performance and Serum Biochemical Indexes in Growing Meat Rabbits. Chinese Journal of Rabbit Farming, No. 2, 22-24.

[30] Northeast Agricultural University (2001) Veterinary Clinic Diagnosis. 3rd Edition, Chinese Agricultural Publish, Beijing.

[31] Yan, Z.H., Wang, J.Q., Wang, M., Bu, D.P., Wei, H.Y., Zhou, L.Y., Zhou, Z.F. and Sun, P. (2010) Effects of Add DDGS on Dairy Blood Biochemical Indexes in Diets. Acta Agriculturae Boreali-Sinica, 25, 179-183.

[32] Mahan, D.C. and Parrett, N.A. (1996) Evaluating the Efficacy of Selenium-Enriched Yeast and Sodium Selenite on Tissue Selenium Retention and Serum Glutathione Peroxidase Activity in Grower and Finisher Swine. Journal of Animal Science, 74, 2967-2974. https://doi.org/10.2527/1996.74122967x

[33] Mahan, D.C. (1999) Effects of Dietary Levels of Selenium-Enriched Yeast and Sodium Selenite as Selenium Sources Fed to Growing-Finishing Pigs on Performance, Tissue Selenium, Serum Glutathione Peroxidase Activity, Carcass Characteristics, and Loin Quality. Journal of Animal Science, 77, 2172-2179.

https://doi.org/10.2527/1999.7782172x 